\begin{tabular}{ll}
\hline 総 & 説 \\
\hline
\end{tabular}

中耳粘膜を介するガス交換

一文献的考察 -

田辺 牧人・高橋 晴雄・本庄篇

\title{
Gas Exchange in Middle Ear through the Mucosa
}

\author{
Makito Tanabe, Haruo Takahashi and Iwao Honjo \\ (Kyoto University Graduate School of Medicine)
}

\begin{abstract}
Ventilation of the middle ear is of two types : 1) ventilation via the eustachian tube and 2) ventilation via the middle ear mucosa. Ventilation via the middle ear mucosa is performed by gas exchange between the middle ear and the blood. The gas composition of the middle ear differs from that of air and resembles that of venous blood. The gas composition and the pressure of the middle ear may be affected by the gas composition of blood and the condition of the middle ear mucosa. When there is a difference in partial pressure between the middle ear and the blood, gas diffuses through the mucosa to equalize the partial pressures. Gas exchange in the middle ear through the mucosa is due to diffusion which depends on the difference in partial pressure. It is not known whether gas exchange between the middle ear and the blood occurs only by gas diffusion between the middle ear and blood and depends on differences of partial pressure.
\end{abstract}

Key words : gas exchange, middle ear, gas composition, gas diffusion

\section{はじめに}

中耳腔が換気されて，大気圧と平衡を保つことは，中 耳の伝音機能を維持する上で重要である.この中耳腔の 換気には，経耳管的換気と経粘膜的換気の 2 つがあり， このうち経耳管的換気については, 以前から多く論じら れ, 中耳の病態との関係も浪湆明らかとなっている1).

一方, 経粘膜的換気についても, 以前から注目されてお り現在その詳細が解明されつつあるが，な怙不明な点が 少なくない，そこで，この経粘膜的換気，つまり中耳粘 膜を介するガス交換について，今後研究を続けていく上 での資料に，この分野の報告につき文献的考察を行った。
中耳圧の変化，中耳粘膜を介するガスの移動

以前より，耳管機能が不良で経耳管的換気が行われな い場合，中耳腔内のガスが吸収され，中耳腔は陰圧化す るとされている2). 経耳管的換気が行われない状態で 中耳圧を測定すると，これが次第に陰圧化することを Proud 5 ${ }^{3)}$, Cantekin 54) は示し，これは中耳粘膜から のガスの吸収によるものと考えた。一方 Thomsen ら5 は，全身麻酔下に笑気を吸入すると，中耳珐が上昇する ことを示した。このことを利用して，大野ら ${ }^{6)}$, 高橋 ら 78) は, 笑気吸入後の中耳圧の変化を測定した結果, 正常耳ではすべてで中耳圧は上昇し，これは笑気が中耳 粘膜を介して, 中耳腔内に拡散することによると考皇た. また Levy ら ${ }^{9)}$ は，溶解度の大きい不活性ガス (Freon-22) 
を吸入した場合，正常耳の中耳腔でそのガスを検出し， 血液中から中耳腔へのガスの拡散を直接的に証明した. これらの結果からも，中耳粘膜を介する中耳腔と血中と のガスの移動は明らかであり，これが中耳粘膜のガス交 換といえる.

組織学的にみると，肺胞ほど豊富ではないが，中耳粘 膜内にもガス交換を行うに十分な毛細血管が存在する10). その毛細血管の一部は繊毛細胞間隙を走行し，その壁が 気相に接していることが報告されている11)。この内皮細 胞は, 血管の内外に多数の突起をのばし，物質の交換が 旺盛であると考えられている1112)。

では，ガスは何故移動するのだろらか？ Hergils ら ${ }^{13)}$ は, 睡眠時には讌下回数が少なく, 経耳管的換気 が減少することを利用して, 睡眠直後の起床時の正常耳 の中耳圧を測定した結果，中耳腔は陽圧を示した．その 原因を調べるため，睡眠時の呼吸パターンである浅い呼 吸を正常耳に負荷した場合中耳圧は上昇し，逆の状態で ある頻回呼吸では中耳圧は下降した ${ }^{13)}$ 。この結果から, 睡眠時のよらな浅い呼吸下では, 血液中の二酸化炭素濃 度が上昇し，それが中耳腔に拡散するために中耳圧が上 昇し, 逆に頻回呼吸では血液中の二酸化炭素濃度が下降 し，それが中耳腔から外へ出ていくために圧が下降する

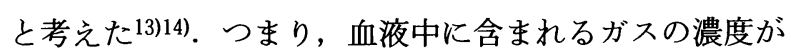
変化すると，それに伴い中耳粘膜を介してそのガスが移 動してガス交換が行われることになる. 大久保 ${ }^{11)} は$, 血液中と中耳腔の酸素濃度を測定し, 血液中の酸素濃度 を上げると中耳腔の酸素分圧は上昇し, 血液中の酸素濃 度を下げると中耳腔の酸素分圧は下降する結果を得た.

こうして血液中のガスの濃度の変化が, 血液と中耳腔と の間でのガス移動をもたらしたといえる.

岩野ら ${ }^{15)}$ は, 正常耳に大気を陽圧, 陰圧で負荷し, 燕下を禁止した場合の中耳压の变化を測定したところ， いずれの場合も負荷された压変化を解消する方向, つま り大気圧に近づく方向に変化することを報告した．

Hergils ら ${ }^{16)}$ は, 同様に耳管からの換気がない状態で中 耳腔に陰圧を負荷した場合は，中耳圧はわずかに上昇し， 軽度の陰圧で安定するとした。これは中耳腔と大気との 間に圧差が生じた場合, その圧差を解消する方向に中耳 粘膜を介してガスが移動することによるものと考えられ， また中耳腔のガスと血液中のガスとは, それぞれが中耳 粘膜を間にして平衡状態を保っているものと考穴られる. そして, 血液中のガスの量の変化や, 中耳圧の変化でこ
の平衡状態が崩れると，それぞれのガスが分圧勾配に従 って新しい平衡状態になるように粘膜を介して移動する ものと考えられる.

それではガス交換は粘膜の影響をどのようにうけるの であろらか? 大野ら ${ }^{6)}$, Takahashi ら ${ }^{8)}$ は, 笑気吸入 時の中耳圧の上昇率と年齢とは負の相関を示すことを見 出し, この結果から, 小児では中耳粘膜を介するガス交 換が活発であること，またこれは小児の中耳粘膜の性状 に由来する可能性を示唆した688)。また高橋ら ${ }^{788}$ は, 笑 気吸入時の出性中耳炎耳では, 中耳圧が上昇しない例 もあり, これらは中耳腔の貯留液や粘膜の炎症が, 中耳 粘膜のガス交換能に影響を及ぼしているものと考えた. 岩野ら ${ }^{15)}$ は, 正常耳と渗出性中耳炎耳の中耳腔を種々 のガスで置換して中耳压を測定し，參出性中耳炎耳では 中耳腔のガスは酸素が吸収されて減少する方向に変化し ていると考皃た。同様に大久保ら ${ }^{17)}$ は炎症の強い中耳 腔のガスは, 炎症のない中耳腔と比べて, 酸素は少なく 二酸化炭素は多いといら結果を示した。しかし一方, 閉 鎖腔に胸膜炎の胸水を注入すると，漸次陰圧化すること

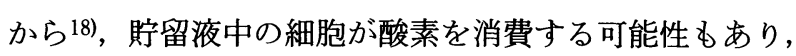
炎症により粘膜の酸素消費が増大するか否かは，な打検 討が必要と考兄られる. Takahashi $5^{8)}$ は, 慢性中耳炎 の手術時に乳突蜂巣を完全に削開すると, 再生洀痕では 笑気吸入による中耳圧上昇はみられないことから，瘢痕 組織はガス交換をし得ないと述べた.

これらをまとめると, 中耳粘膜のガス交換は, 中耳粘 膜の性状や中耳腔の状態の影響をらけるものと考兄られ る.

それでは，中耳腔のガスと，血液中のガスとはどのよ らな状態で平衡を保っているのであろらか？これを知 るためには中耳腔内のガス組成を知る必要がある.

\section{中耳腔のガス組成}

前述のように, 中耳腔は経耳管的換気と経粘膜的換気 をらけているが，中耳腔のガス組成はどちらの影響を強 くらけているのであろらか?

質量分析法により混合気体の組成，および液体に含有 されるガス量が正確に定量できるようになり，それを用 いて中耳腔のガス組成が測定されている，大久保ら ${ }^{17)}$ は, 正常耳の中耳腔のガス組成は, 窒素 596.7 44.7 $\mathrm{mmHg}$, 酸素 $65.4 \pm 5.9 \mathrm{mmHg}$ ，二酸化炭素 $44.6 \pm 3.6$ $\mathrm{mmHg}$ であり, そのガスの構成要素は大気と同じであ 
るが，組成は違らことを報告した. Luntzら ${ }^{199}$ は, 正 常耳の中耳腔と，それに粘膜を介して接している静脈血 のガスの組成を同時に連続的に測定した結果, 二酸化炭 素の分圧は中耳腔と静脈血とではかなり類似しており， 酸素も比較的近い分圧を示すが，窒素はそれほどではな いといら結果を得た．そしてこの違いは，各々の気体の 拡散速度の違いによるものであり, 二酸化炭素は拡散速 度が速く, 窒素は遅いためであるとした。 そして, 中耳 腔の酸素と二酸化炭素の組成は，静脈血や中耳腔周囲の 粘膜組織と，中耳腔との間のガス交換によって調節され ているものと考えた19).

以上の結果は, 中耳腔のガス組成, 特に酸素々二酸化 炭素については, ガス分圧が, 静脈血中のガス分圧と近 い值をとることを示するのといえ，中耳粘膜を間にした 中耳腔と血液中の平衡状態とは，それぞれのガス分圧が 等しくなる状態を示すと考えられる.

\section{中耳粘膜のガス交換}

以上より中耳粘膜のガス交換とは，中耳粘膜を境にし た中耳腔と血液との平衡状態が何らかの原因(血液中に 含まれるガスの分圧が変化したときや，中耳圧が経耳管 的に変化したときなど)で崩れ，両者の間のガス分圧に 差が生じた場合に，その差を解消するように各種ガスが 中耳粘膜を介して拡散, 移動することといえる. しかし, この拡散の速さは，ガスの種類によって違っており，二 酸化炭素, 酸素, 窒素の順に速い(19) 22). その上, 肺胞 に拈けるガス交換汪ど短時間に行えないため，ある程度 の時間を要し, 各種ガスの間でも時間差があるため, 中 耳圧の変化としてとらえることができるものと考えられ た.

それでは，いわゆる定常状態ではガス交換はどのよう になっているのだろらか？ ガス交換は，中耳粘膜を介 して中耳腔と血液との間にガス分圧の差が生じた場合の 拡散だけなのであろらか？ 耳管が閉塞した場合の中耳 腔の陰圧化を説明できるようなガス交換が行われている のだろらか？ Proud ら ${ }^{3)}$, Cantekin ら ${ }^{4)}$, Takahashi ら ${ }^{23)}$ は，耳管を閉塞した場合に，中耳腔は陰圧化する が，どこまででも陰圧化するわけではなく，あるところ で安定することを示し, Hergils ら 16) も，経耳管的換気 がない状態で中耳腔に陰圧を負荷すると，陰圧は進まず に逆に圧は上昇し，軽度陰圧となることを示した．これ らは, 経粘膜的換気だけの場合, 中耳腔は軽度の陰圧の
状態で平衡状態になるといえる，Matumura ${ }^{24)}$ は，耳管 狭窄耳の中耳腔の酸素量が正常耳と比べて低いことから， 酸素が粘膜から吸収され，耳管からの換気でそれが補わ れるとした. Ostfeld ら ${ }^{211}$ は，中耳腔内では主として， 代謝活性ガスである酸素, 二酸化炭素が中耳粘膜を介し て移動するとしたまた，中耳腔内の粘膜組織中の各種 ガス分圧の合計が，大気圧よりやや低いため，そこで生 じるガス分圧差に従ってガスが粘膜に吸収され，徐々に 中耳腔は陰圧となり，耳管の開大によりガスが補われる とした21).これらはいずれも経耳管的換気がない場合に 中耳腔が陰圧化する説明となるが，その陰圧はある程度 で留まることになる。

Doyle ら 2225) は, 酸素, 二酸化炭素は中耳粘膜を介し て比較的速く移動するが，窒素はその移動がかなり遅く， 生理学的にも酸素, 二酸化炭素のガス交換はdiffusionlimited であり, 窒素のガス交換は perfusion-limited で あるとした．しかし，実際のガス交換の速度からは，ど の気体も diffusion-limited である可能性があるとしてい $3^{25)}$.

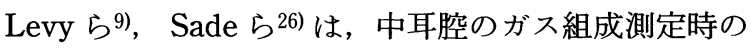
ガス分圧の変化から, 水, 二酸化炭素は主に中耳腔に入 る方向に拡散し, 酸素, 窒素は主に中耳腔からでていく 方向に拡散しており, 炎症により粘膜の血流が増加する と, ガス交換能が増大し, 酸素や窒素が “washout”さ れるために陰圧になるとした。

この様に, 酸素, 二酸化炭素が分圧差に上る拡散で移 動しているのは確かであるが, 窒素などの他のガスにつ いては種々の説がある. しかし, 炎症などで修飾される にしても, 中耳粘膜が能動的にガスを移動させるような 機能を持っているとは考注くく, 基本的には, 中耳腔 と血液との間のガスの分压差に従って, 受動的にガスが 移動するものと考えられる. しかし，ガスの種類によっ て，その移動の速度に大きな差があるため，それが中耳 圧の変化となって現れるものと考兄られる. また, 中耳 腔粘膜のガス分圧が，大気圧よりも低いため，その圧差 により中耳腔内のガスが中耳粘膜に吸収され，耳管が開 放したときにガスが補われることになる。しかし耳管が 閉塞した場合には，このガス補充がないため，中耳腔内 は陰圧となると考兄られる。

今後, 出性中耳炎, 真珠腫性中耳炎, 瘉着性中耳炎 等の中耳の炎症性疾患で, 粘膜ガス交換がどのようにな っているか, それが疾患の病因, 病態とどの上うに関連 
しているかが解明されれば，治療上の一助になるものと

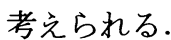

\section{まとめ}

中耳腔のガス組成は，特に二酸化炭素，酸素について は大気ではなく, 静脈血のガス組成に近いことがわかっ ている、このことから，中耳腔と血液とは，それぞれに 含をれる各種ガスの分圧が，中耳粘膜を介して等しくな るように平衡を保っていると考えられる，一方血液中の ガスの濃度が変化したり, 中耳厈が変化すると，この平 衡状態が崩れ，中耳粘膜を介して中耳腔と血液との間に 生じた分圧差で，ガスの拡散が受動的に括こる。これが 中耳粘膜のガス交換といえる. またこのガス交換は, 二 酸化炭素, 酸素, 窒素の順に速い.

定常状態では, 中耳腔周囲の粘膜, 血液中のガス分圧 の総和が大気圧よりもわずかに低いため, 中耳腔は周囲 組織のガス分圧に近づき, 大気圧と比べて常に軽い陰圧 になる。ここで中耳圧が大気圧になるように，耳管から の換気をらけるが，この経耳管的換気がなくなれば，中 耳腔は軽度の陰圧となる。

一方, 炎症の要因が加わった場合は, 代謝充進に伴い 酸素の消費が亢進したり, 粘膜ガス交換が障害される, などの報告があるが未だ一致した見解は得られていない．

\section{参考文献}

1) 本庄 㒈: 耳管と中耳病態. 進行印刷出版, 京都, 1987.

2) Zaufal E : Über das Vorkmmen serö ser Flü ssigkeit in der Paukenhöhle (Otitis Media Seron). Arch Ohrenheikd 5 : $38 \sim 81,1870$.

3) Proud GO, Odoi $\mathrm{H}$ and Toledo PS : Bullar pressure changes in eustachian tube dysfunction. Ann Otol Rhinol Laryngol $80: 835 \sim 837,1971$.

4) Cantekin EI, Doyle WJ, Phillips DC, et al : Gas absorption in the middle ear. Ann Otol Rhinol Laryngol 89 Suppl $68: 71 \sim 75,1980$.

5 ) Thomsen KA, Terkildsen K and Arnfred I : Middle ear pressure variations during anesthesia. Arch Otolaryngol $82: 609 \sim 611,1965$.

6 ）大野文夫, 今給黎泰二郎, 昇 卓夫, 他: 中耳粘膜を介す る中耳換気能 一笑気吸入による中耳圧变化より一。昁 鼻 $96: 1861 \sim 1868,1993$.

7 ) 高橋晴雄, 本庄 孷, 倉田響介, 他 : 笑気ガスによる中耳 ガス交換能評価の試み。耳鼻臨床 $87: 885 \sim 889,1994$.

8) Takahashi H, Sugimaru T, Honjo I, et al : Assessment of the gas exchange function of the middle ear using nitrous oxide. Acta Otolaryngol (Stockh) $114: 643 \sim 646,1994$.
9 ) Levy D, Herman M, Luntz M, et al : Direct demonstration of gas diffusion into the middle ear. Acta Otolaryngol (Stockh) $115: 276 \sim 278,1995$.

10) Buckingham RA, Stuart DR, Geick MR, et al : Experimental evidence against middle ear oxygen absorption. Laryngoscope $95:$ 437 442, 1985.

11）大久保代：大気圧環境の中耳腔能動換気について一Dynamic aeration physiology of the middle ear air-space- . 耳 展 $36: 251 \sim 270,1993$.

12）大久保仁 : 乳突蜂巣粘膜下毛細血管の電子顕微鏡像. 中耳 腔の換気. 28〜32頁, 総合医学社, 東京, 1990 .

13) Hergils $L$ and Magnuson $B$ : Morning pressure in the middle ear. Arch Otolaryngol $111: 86 \sim 89,1985$.

14) Bylander ANK, Ivarsson $A$, Tjernstrom $O$, et al : Middle ear pressure variations during 24 hours in children. Ann Otol Rhinol Laryngol 94 Suppl $120: 33 \sim 35,1985$.

15）岩野 正, 土井 直, 細田泰男, 他：中耳腔に佂斿経粘 膜的圧調節機構について. 耳鼻臨床 $86: 1265 \sim 1272,1993$.

16) Hergils $L$ and Magnuson $B$ : Regulation of negative middle ear pressure without tubal opening. Arch Otolaryngol Head Neck Surg $114: 1442 \sim 1444,1988$.

17）大久保化，野城真理：質量分析装置による中耳腔ガス組成 の分析一中耳腔のガス代謝一. 日耳鼻 $97: 1181 \sim 1190$, 1994.

18）本庄 瞰：いわゆる中耳のガス交換能について。耳鼻臨床 $87: 1 \sim 5,1994$.

19) Luntz M, Levy D, Herman M, et al : Relationship between the gas composition of the middle ear and the venous blood at steady state. Laryngoscope $105: 510 \sim 512,1995$.

20) Sade J and Luntz M : Gas diffusion in the middle air. Acta Otolaryngol (Stockh) $111: 354 \sim 357,1991$.

21) Ostfeld EJ and Silberberg A : Composition and pressure in the middle ear; a model for the physiological steady state. Laryngoscope $101: 297 \sim 304,1991$.

22) Doyle WJ and Seroky JT : Middle ear gas exchange in rhesus monkeys. Ann Otol Rhinol Laryngol 103 : 636 645, 1994.

23) Takahashi H, Fujita A, Lee SH, et al : Experimental conditions for the development of persistent otitis media with effusion. Arch Otorhinolaryngol (Eur) 247 : 89 92, 1990.

24) Matumura $H$ : Studied on the composition of air in the tympanic cavity. Arch Otolaryngol $61: 220 \sim 222,1955$.

25) Doyle WJ, Seroky JT and Alper CM : Gas exchange across the middle ear mucosa in monkeys. Arch Otolaryngol Head Neck Surg 121 : 887 892, 1995.

26) Sade J, Luntz M and Levy D : Middle ear gas composition and middle ear aeration. Ann Otol Rhinol Laryngol 104 : 369 373, 1995.

$\left.\begin{array}{l}\text { 原稿受付: 平成 } 7 \text { 年11月 } 8 \text { 日 } \\ \text { 原稿採択 : 平成 } 7 \text { 年11月 } 29 \text { 日 } \\ \text { 別刷請求先 : 田辺牧人 } \\ \text { 干606-01 京都市左京区聖護院川原町 } 54 \\ \text { 京都大学大学院医学研究科感覚運動系病態学講座 } \\ \text { 聴覚・言語病態学領域 }\end{array}\right)$

